\title{
Distribusi Spasial dan Temporal Petir di Sumatera Barat
}

\author{
Elfira Saufina, Marzuki* \\ Jurusan Fisika Universitas Andalas \\ *marzuki@fmipa.unand.ac.id
}

\begin{abstract}
ABSTRAK
Distribusi spasial dan temporal petir di Sumatera Barat telah diteliti dengan menggunakan data satelit Tropical Rainfall Measuring Mission-Lightning Imaging Sensor (TRMM-LIS) selama 16 tahun pengamatan (1998-2013). Hubungan antara petir dan curah hujan diteliti dengan memanfaatkan data TRMM 3B43. Hasil penelitian menunjukkan bahwa petir di Sumatera Barat banyak terjadi di darat dengan densitas tertinggi terjadi pada bulan Desember, Januari dan Februari (DJF). Petir di darat banyak terjadi pada sore hari mulai jam 17.00 LST hingga tengah malam dan kabupaten Dharmasraya merupakan daerah yang memiliki densitas kilatan petir tertinggi terutama selama periode DJF. Siklus diurnal petir konsisten dengan siklus migrasi awan dari laut ke daratan Sumatera yang ditemukan oleh peneliti sebelumnya. Hubungan curah hujan dan petir di Sumatera Barat bervariasi antara satu kabupaten dengan kabupaten lainnya. Berdasarkan nilai regresi linier antara petir dan curah hujan terlihat bahwa daerah yang memiliki korelasi yang cukup kuat antara densitas petir dan curah hujannya adalah Kabupaten Solok, Solok Selatan, Padang Pariaman, dan 50 Kota sedangkan daerah yang memiliki korelasi yang rendah adalah Kepulauan Mentawai, Pesisir Selatan, dan Agam. Dengan demikian, di beberapa kabupaten petir dapat menjadi indikator untuk penentu curah hujan tetapi tidak untuk beberapa kabupaten yang lain. Kata kunci: distribusi petir, Sumatera Barat, TRMM
\end{abstract}

\begin{abstract}
Spatial and temporal distribution of lightning in West Sumatra had been investigated by using 16 years of Tropical Rainfall Measuring Mission-Lightning Imaging Sensor (TRMM-LIS) observation. Total rainfall of TRMM 3B43 was used to study the relationship between lightning and rainfall. It was found that lightning over land was more dominant than over the ocean and coastal region. The lightning showed diurnal variation and the largest number of lightning was observed during the afternoon and evening with a peak around 17:00 LST. The diurnal cycle of lightning coincided with the diurnal cycle of cloud migration from the ocean to the inland of Sumatra as reported by previous researchers. The relationship between rainfall and lightning in West Sumatra varied from one district to another. A strong correlation between the two parameters was observed for the district of Solok, Solok Selatan, Padang Pariaman, and 50 Kota. On the other hand, low correlation was observed for Mentawai Islands, Pesisir Selatan, and Agam. Thus, lightning can be an indicator for surface rainfall in some districts but not for others. Keywords:lightning distribution, West Sumatra, TRMM
\end{abstract}

\section{PENDAHULUAN}

Petir (lightning) merupakan pelepasan arus listrik yang tinggi di atmosfer dengan jarak penjalaran beberapa kilometer. Pelepasan arus listrik diawali dengan pemisahan muatan positif dan muatan negatif di dalam awan. Proses pemisahan muatan mengakibatkan muatan positif terdistribusi di bagian atas awan sedangkan muatan negatif terdistribusi di bagian bawah. Muatan negatif di bagian bawah awan akan ditarik oleh gravitasi bumi yang menyebabkan terjadinya pelepasan muatan sehingga terjadilah petir (Uman, 2001).

Petir melepaskan arus listrik yang tinggi dalam rentang waktu yang singkat. Diperkirakan bahwa petir melepaskan arus listrik sebesar 80.000 A dalam satu kali sambaran sedangkan total daya rata-rata yang dilepaskan secara serentak oleh petir dalam satu kali sambaran sekitar $10^{6} \mathrm{~W}$. Pelepasan daya ini terjadi dalam benda rentang waktu yang singkat yaitu selama 0,5 detik untuk beberapa sambaran (Valdivia, 1997; Hutchins dkk., 2012; Zheng dkk., 2016).

Besarnya energi yang dilepaskan oleh petir, menimbulkan dampak terhadap yang dikenainya. Dampak petir yang paling berbahaya bagi manusia adalah kematian. Kematian atau korban jiwa dapat disebabkan oleh sambaran langsung maupun akibat reruntuhan bangunan yang terkena sambaran petir. Lopez dkk. (1995) melaporkan 103 kasus kematian, 299 korban luka dan 191 kerusakan yang disebabkan oleh petir di Colorado dari tahun 1950 hingga 1991. Sementara itu, Cardoso (2014) mencatat 1321 korban jiwa akibat sambaran petir atau 132 kasus per tahun di Brazil dari 2000 hingga 2009. Dampak merugikan lain yang dapat ditimbulkan 
petir adalah kerusakan jaringan telekomunikasi, jaringan listrik, dan gangguan penerbangan (Uman, 2001).

Besarnya dampak yang ditimbulkan oleh petir telah mendorong pengembangan berbagai instrumen untuk mengamatinya. Instrumen tersebut antara lain satelit Tropical Rainfall Measuring Mission-Lightning Imaging Sensor (TRMM-LIS), Optical Transient Detector (OTD), Lightning Detection and Ranging System (LDAR), dan World Wide Lightning Location Network (WWLLN). Perkembangan sistem pengamatan petir telah meningkatkan pengetahuan tentang karakteristik petir salah satunya adalah distribusi petir terhadap lintang.

Petir di kawasan lintang yang berbeda memiliki densitas kilatan yang berbeda. Densitas kilatan petir di daerah beriklim tropis terutama di daerah ekuator lebih tinggi dibandingkan dengan daerah di lintang menengah dan kutub. Valdivia (1997) menemukan bahwa jumlah petir secara umum lebih banyak di ekuator yaitu sekitar 100 sambaran per sekon. Jumlah ini lebih besar jika dibandingkan dengan daerah subtropis yaitu 1,5 sambaran per menit atau 0.025 sambaran per detik (Seaman, 2000). Hal ini disebabkan oleh temperatur daerah tropis yang lebih tinggi sehingga penguapan yang terjadi juga lebih banyak. Proses penguapan akan membentuk awan-awan hujan yang sangat potensial untuk menghasilkan petir (Carey dan Rutledge, 2000). Tingginya curah hujan di ekuator berkorelasi dengan tingginya densitas kilatan petir (Soula, 1998).

Indonesia terutama Pulau Sumatera terletak di kawasan ekuator sehingga diperkirakan densitas kilatan petirnya tinggi yang akan berdampak terhadap manusia. Virts dkk. (2013) secara umum telah memetakan klimatologi petir global termasuk Sumatera yang menunjukkan bahwa densitas kilatan petir di Pulau Sumatera lebih tinggi pada malam hari dibandingkan siang hari. Selain itu, Septiadi dan Hadi (2011) juga telah melakukan penelitian mengenai hubungan petir dan curah hujan di Jawa Barat dan menemukan bahwa pada bulan Maret 2009 terdapat hubungan yang kuat antara petir dan hujan dengan koefisien korelasi 0,998. Dari penelitianpenelitian tersebut terlihat bahwa tingkat kerawanan petir bervariasi antara satu daerah dengan daerah lainnya.

Untuk kawasan Sumatera Barat baru ditemukan satu penelitian yang membahas tentang petir yaitu Vadreas dkk. (2014). Mereka telah memetakan sambaran petir di Sumatera Barat selama 2 bulan pengamatan (Mei-Juli 2014). Selama periode pengamatan tersebut mereka mengamati 200 sambaran petir di Sumatera Barat. Penelitian ini akan menganalisis distribusi spasial dan temporal petir Sumatera Barat menggunakan data yang lebih lama dari Vadreas dkk. (2014). Data yang digunakan adalah data dari satelit Tropical Rainfall Measuring MissionLightning Imaging Sensor (TRMM-LIS) selama tahun 1998 hingga tahun 2013 (16 tahun).Pada penelitian ini juga akan didiskusikanfaktor-faktor yang mempengaruhi densitas kilatan petir di Sumatera Barat.

\section{METODE}

Data yang digunakan dalam penelitian ini adalah data petir dari satelit TRMM-LIS selama 16 tahun pengamatan dari Januari 1998-Desember 2013. Data yang digunakan adalah data versi 7 dengan resolusi spasial data $0.1^{\circ}$ dan resolusi temporal 1 bulan dan 1 jam. Data ini berisi beberapa parameter yaitu latitude, longitude, VHRFC_LIS_FRD (data tahunan), VHRMC_LIS_FRD (data bulanan) dan VHRDC_LIS_FRD (data diurnal atau jam-an). Selain itu, digunakan juga data curah hujan TRMM 3B43 dengan resolusi temporal bulanan dan resolusi spasial $0,25^{\circ}$ x 0,25 dari Januari 1998 - Desember 2013. Data TRMM 3B43 digunakan untuk mengamati hubungan antara densitas kilatan petir dan curah hujan.

Dalam penelitian ini pengolahan data dilakukan dengan menggunakan software MATLAB. Data petir diunduh dari website NASA berbentuk grid dalam format NetCDF. Data tersebut tersedia untuk cakupan wilayah $35^{\circ} 00^{\prime}$ LU hingga $35^{\circ} 00^{\prime} \mathrm{LS}$ dan $180^{\circ} 00^{\prime} \mathrm{BB}$ hingga $180^{\circ} 00^{\prime} \mathrm{BT}$. Data petir diseleksi untuk daerah Sumatra Barat yaitu pada $0^{\circ} 5^{\prime}$ ' LU dan $3^{\circ} 30^{\prime}$ LS serta 98 $36^{\prime}$ BT dan $101^{\circ} 53^{\prime}$ BT.

Distribusi spasial petir per tahun di Sumatera Barat ditampilkan dalam bentuk plot kontur sedangkan untuk mengamati hubungan distribusi petir terhadap variasi bulanan plot data petir bulanan dikelompokkan per tiga bulan pengamatan yaitu DJF (Desember, Januari, 
Februari), MAM (Maret, April, Mei), JJA (Juni, Juli, Agustus), dan SON (September, Oktober, November). Pengelompokan ini didasarkan kepada kesamaan pola angin, awan dan hujan pada bulan-bulan tersebut (Marzuki dkk., 2013). Selain itu, untuk mengamati distribusi diurnal petir ditampilkan plot kontur data petir selama 24 jam dengan pengelompokan per 4 jam pengamatan, Dari plot diurnal ini dapat diamati pola temporal petir di Sumatera Barat.

Data curah hujan ditampilkan dalam bentuk kontur dengan periode pengamatan yang sama dengan data petir yaitu DJF, MAM, JJA dan SON untuk mengamati intensitas curah hujan yang terjadi di Sumatera Barat. Hasil plot hujan ini kemudian dibandingkan dengan plot data petir untuk mengamati hubungan antara petir dan curah hujan di Sumatera Barat. Analisis regresi dilakukan untuk mengamati korelasi yang lebih jelas antara petir dan curah hujan dengan menghubungkan data petir dan curah hujan per kabupaten di Sumatera Barat dalam grid $0,25^{\circ}$. Dari analisis regresi ini akan terlihat kabupaten mana saja di Sumatera Barat yang memiliki hubungan yang kuat antara petir dan curah hujannya.

\section{HASIL DAN DISKUSI}

\subsection{Distribusi Spasial dan Bulanan Petir Sumatera Barat}

Gambar 1 memperlihatkan rata-rata petir per tahun per kilometer di Sumatera Barat menggunakan data TRMM selama 16 tahun pengamatan (1998-2013). Intensitas petir di Sumatera Barat bervariasi antara satu kabupaten dengan kabupaten lainnya. Secara umum, semakin jauh lokasi suatu kabupaten dari laut, semakin tinggi intensitas petir kabupaten tersebut. Intensitas petir di atas $40 \mathrm{flash} / \mathrm{km}^{2} /$ tahun teramati di Kabupaten Pasaman, 50 Kota, Sijunjung, Solok, Solok Selatan dan Pesisir Selatan. Semua kabupaten ini jauh dari laut kecuali Kabupaten Pesisir Selatan. Kabupaten Mentawai dan lautan sekitar Sumatera Barat mempunyai intensitas petir yang rendah $\left(<5\right.$ flash $\left./ \mathrm{km}^{2} / \mathrm{tahun}\right)$.

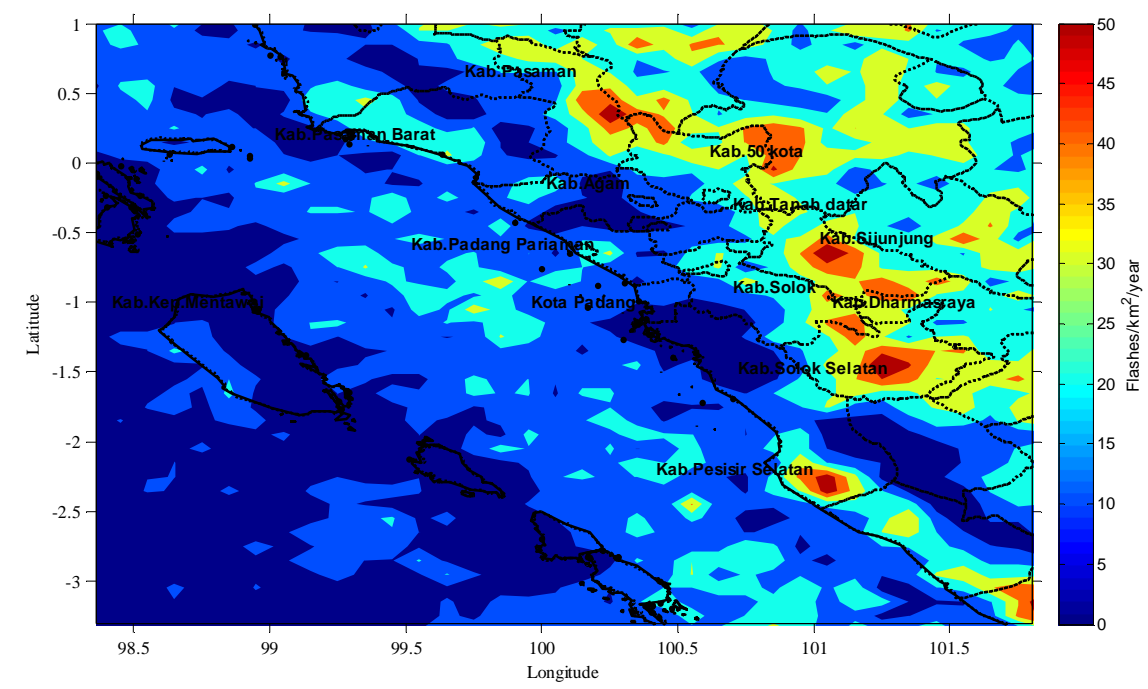

Gambar 1 Distribusi Spasial Kilatan Petir Sumatera Barat (1998-2013)

Perbedaan distribusi petir antara darat dan laut di Sumatera Barat secara umum dapat disebabkan oleh dua faktor. Pertama, daratan memiliki topografi yang lebih tinggi dibandingkan dengan lautan. Di Sumatera Barat terdapat beberapa dataran tinggi yang merupakan deretan pegunungan Bukit Barisan (Gambar 4.2). Kozak (1998) menjelaskan bahwa awan konvektif penghasil petir banyak terjadi di daerah yang lebih tinggi. Kedua,aktivitas konvektif lebih sering terjadi di darat terutama disebabkan oleh kapasitas panas tanah yang lebih rendah dibandingkan air laut, sehingga tanah lebih efektif menghangatkan udara yang meningkatkan pergerakan vertikal keatas (updraft)udara dalam proses konvektif (Albrecht dkk., 2015). Interaksi antara massa udara dari temperatur yang berbeda akan merangsang munculnya badai dan petir (Lay dkk., 2007).

Dari distribusi spasial petir antara darat dan laut, terdapat satu anomali yaitu kabupaten Pesisir Selatan yang menunjukkan densitas kilatan petir yang tinggi sementara posisinya berada di dekat pantai. Hal ini dapat dikarenakan bahwa Pesisir Selatan memiliki kawasan hutan tipe 
Kawasan Suaka Alam-Kawasan Pelestarian Alam (KSA-KPA) yang terluas di Sumatera Barat yaitu 285.420,14 Ha (Dinas Kehutanan Provinsi Sumatera Barat, 2014). Selain itu, Topografinya terdiri dari dataran, gunung dan perbukitan yang merupakan perpanjangan gugusan Bukit Barisan.

Untuk mengamati distribusi spasial petir di Sumatera Barat dalam hubungannya dengan variasi bulanan, data pengamatan dikelompokkan ke dalam empat bulan yaitu Desember, Januari dan Februari (DJF), Maret, April, Mei (MAM), Juni, Juli, Agustus (JJA), dan September, Oktober, November (SON).
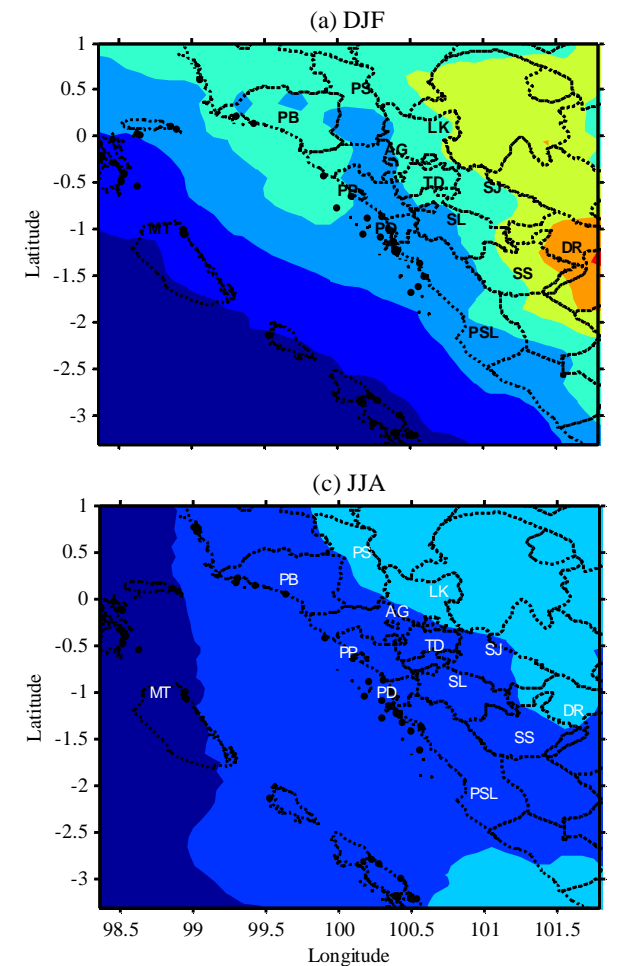

Keterangan :

$$
\begin{array}{ll}
\text { M T = Kep. M entawai } & \text { PB = Pasaman Barat } \\
\text { PP = Padang Pariaman } & \text { PD }=\text { Padang } \\
\text { SS =Solok Selatan } & \mathrm{SL}=\text { Solok } \\
\text { AG =Agam } & \text { TD }=\text { Tanah Datar } \\
\text { DR = Dharmasraya } &
\end{array}
$$
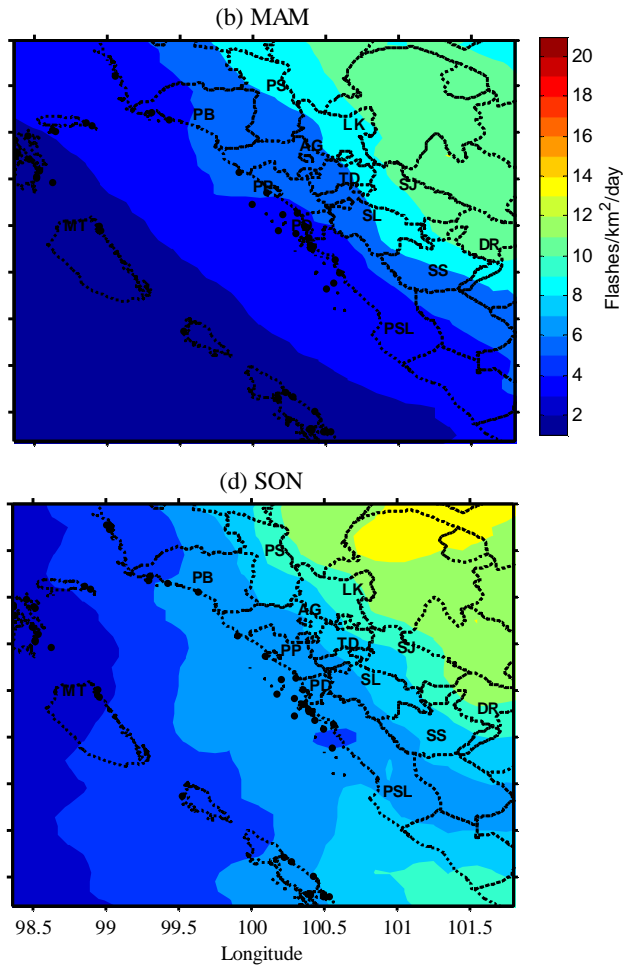

PS = Pasaman

PSL = Pesisir Selatan

SJ = Sijunjung

LK $=50$ Kota

Gambar 2 Distribusi Spasial dan Bulanan Petir Sumatera Barat. a) Desember, Januari,

Februari (DJF). b) Maret, April, Mei (MAM). c) Juni, Juli, Agustus (JJA). d) September,

Oktober,November (SON)

Gambar 2 memperlihatkan distribusi spasial petir di Sumatera Barat untuk DJF, MAM, JJA dan SON. Secara umum, petir teramati pada semua bulan. Namun, intensitas petir selama DJF dan SON lebih tinggi dari periode MAM dan JJA. Hal ini konsisten dengan periode konveksi di Indonesia. Periode konveksi biasanya terjadi ketika angin yang berhembus ke timur dominan dan terjadi selama DJF. Kemudian, selama SON angin ke barat dominan di Indonesia dan awan konvektif hanya dominan di Sumatera dan sebagian Kalimantan. JJA merupakan bulan kering di Indonesia dengan jumlah awan konvektif lebih sedikit dibandingkan bulanbulan yang lain. Selama JJA angin berhembus dari selatan (Australia) menuju utara (Indonesia). Karena angin melalui sedikit lautan selama JJA maka angin tersebut hanya membawa sedikit uap air sehingga awan konvektif sedikit terjadi di Indonesia (Marzuki dkk., 2013).

Intensitas petir maksimum untuk setiap bulan memperlihatkan variasi. Selama periode DJF intensitas petir tertingi teramati di Kabupaten Dharmasraya,dalam rentang menengah yaitu 8-15 kilatan $/ \mathrm{km}^{2} /$ hari. Selama MAM Kabupaten 50 Kota memiliki densitas kilatan tertinggi, dalam rentang menengah yaitu dalam kisaran 5-10 kilatan $/ \mathrm{km}^{2} /$ hari. Selain itu, sebagian Kabupaten Solok, sebagian Kabupaten Solok Selatan, Kabupaten Sijunjung dan Dharmasraya 
juga memiliki intensitas petir yang agak tinggi. Selama JJA daerah yang memiliki densitas kilatan tertinggi adalah Kabupaten Dharmasraya, sebagian Kabupaten Sijunjung, Pasaman dan 50 Kota. Hasil ini cukup mirip dengan penelitian Vadreas dkk. (2014) yang menemukan bahwa jumlah sambaran petir tertinggi selama bulan Juni-Agustus 2014 terjadi di Kota Payakumbuh dan daerah sekitarnya.

Tingginya densitas kilatan petir untuk kabupaten-kabupaten di atas selama periode JJA kemungkinan disebabkan oleh faktor vegetasi. Misalnya, Kabupaten Dharmasraya merupakan kawasan dengan luas daerah tutupan hutan terluas di Sumatera Barat yaitu seluas 1.781.289 Ha (Pemprov Sumatera Barat, 2014). Hal ini sejalan dengan penelitian Kozak (1998) yang menyatakan bahwa vegetasi hutan dapat mendorong aktivitas konvektif di atmosfer yang memicu petir. Untuk periode SON, intensitas petir yang tinggi terjadi di sekitar Kabupaten Dharmasraya, sebagian Kabupaten 50 Kota dan sebagian Kabupaten Sijunjung.

Dari semua Gambar 2 terlihat bahwa daerah yang mengalami densitas kilatan petir tertinggi adalah kabupaten yang jauh dari laut atau pantai. Hal ini disebabkan karena awan yang berpotensial menghasilkan petir adalah tipe awan konvektif yang intensitasnya lebih tinggi di darat (Carey dan Rutledge., 2000). Selain itu, daerah dengan tutupan hutan yang luas juga mempunyai jumlah petir yang lebih banyak dibandingkan daerah yang luas hutannya lebih kecil.

\subsection{Distribusi Diurnal Petir Sumatera Barat}

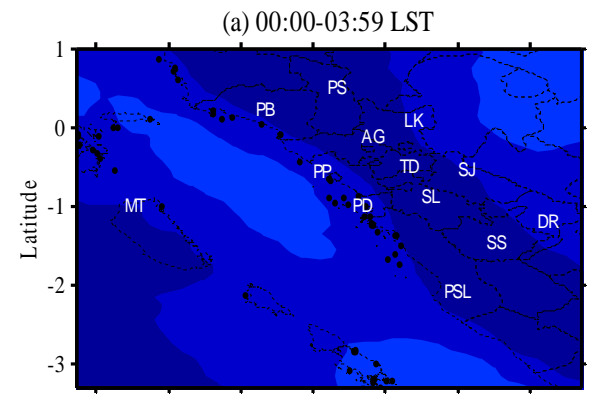

(c) 08:00-11:59 LST

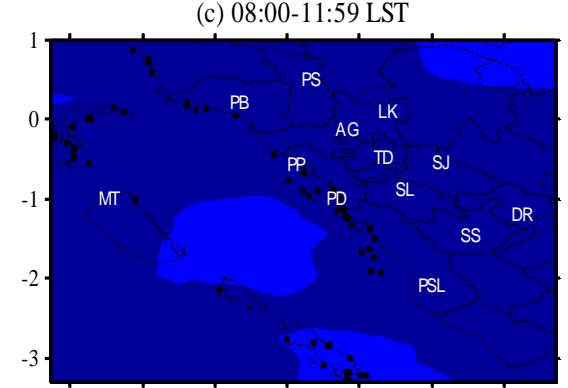

(e) 16:00-19:59 LST

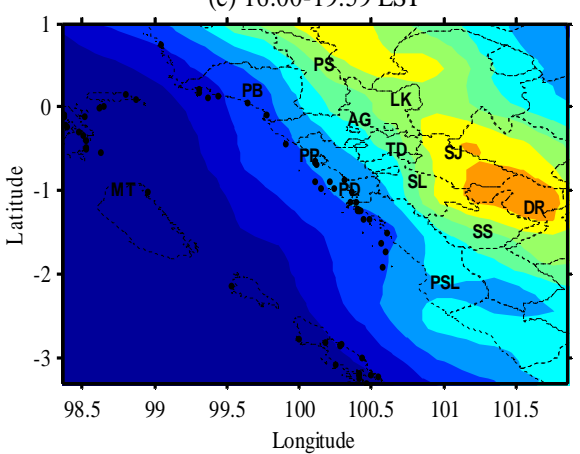

(b) 04:00-07:59 LST

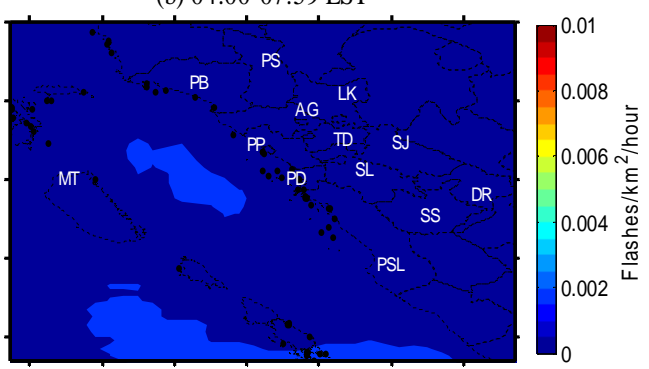

(d) 12:00-15:59 LST

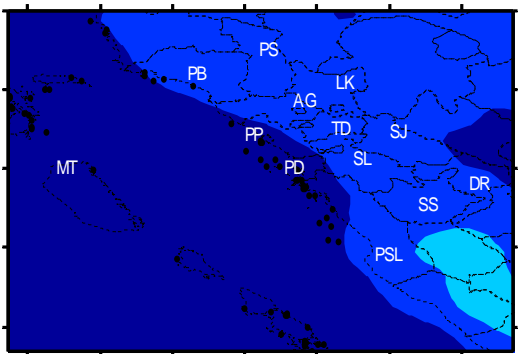

(f) 20:00-23:59 LST

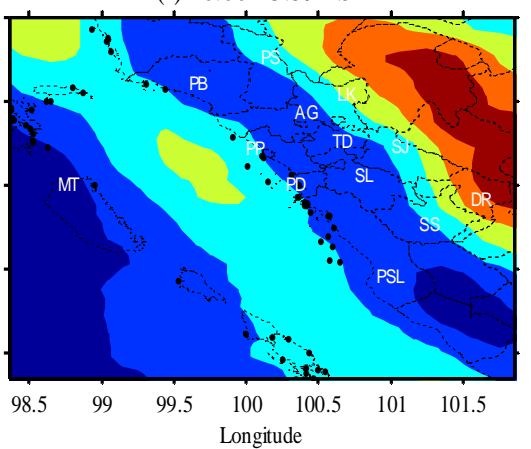

Gambar 3 Distribusi Diurnal Petir Sumatera Barat. a) 00-04 LST. b) 04-08 LST. c) 08-12 LST. d) 12-16 LST. e) 16-20 LST. f) 20-24 LST 
Gambar 3 memperlihatkan distribusi diurnal data petir di Sumatera Barat yang dikelompokkan kedalam empat jam pengamatan waktu setempat atau Local Standard Time (LST).Pada jam 00-04, jumlah petir agak tinggi di sekitar pantai. Hal ini sejalan dengan mulai bergeraknya awan dari daratan Sumatera ke lautan terutama Samudera Hindia bersamaan dengan berhembusnya angin dari darat ke laut (Mori dkk., 2004). Pada jam 04-08, awan hampir tidak ada sehingga petir juga sangat kecil jumlahnya pada jam ini. Petir mulai teramati kembali di lautan selama periode 08-12 seiring dengan mulai meningkatnya intensitas sinar matahari. Awan yang terbentuk di laut ini bergerak ke arah timur (menuju Sumatera) dan mencapai daratan Sumatera mulai jam 13 dan mencapai puncak sekitar jam 17-18 (Marzuki dkk., 2016a), sehingga jumlah petir juga mencapai maksimal pada jam ini. Awan konvektif bertahan di atas Sumatera selama beberapa jam akibat adanya Bukit Barisan (Mori dkk., 2004) sehingga intensitas petir juga tinggi selama beberapa jam di Sumatera Barat (Gambar 3e-f). Pada malam hari (Gambar 3f), awan dari daratan Sumatera mulai bergerak ke laut seiring dengan pergerakan angin dari darat ke laut.Oleh karena itu, jumlah petir di laut mulai tinggi pada malam hari dan berlanjut hingga subuh dan pagi hari.

Dari uraian di atas dapat disimpulkan bahwa pola variasi diurnal petir di Sumatera Barat sangat sesuai dengan siklus pergerakan awan dari laut ke darat (Mori dkk., 2004) dimana intensitas petir yang tinggi di daratan terjadi pada sore dan malam hari sesuai dengan fase maksimum kemunculan awan konvektif di daratan. Hasil ini sesuai dengan penelitian Virts dkk. (2013) yang menyatakan bahwa densitas kilatan petir Pulau Sumatera lebih tinggi pada malam hari dibanding pagi dan siang hari.

\subsection{Hubungan Petir dan Curah Hujan}

(a) DJF

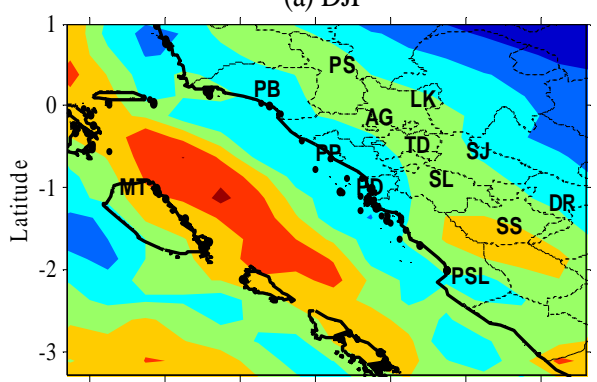

(c) JJA

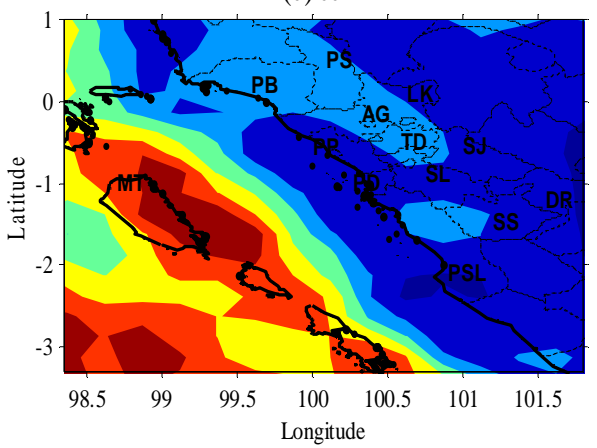

(b) MAM

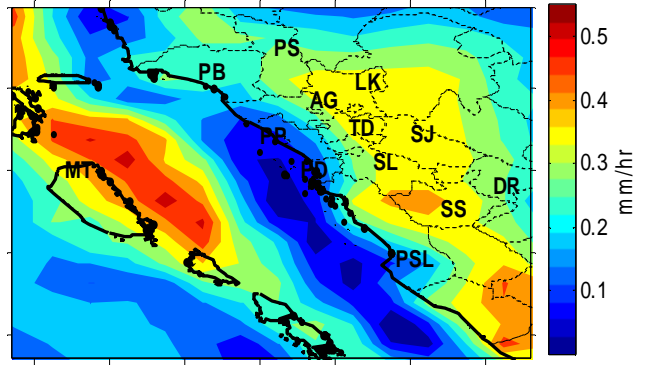

(d) $\mathrm{SON}$

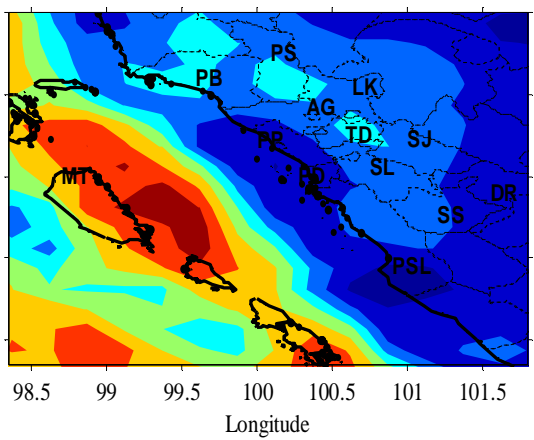

PS = Pasaman

PSL = Pesisir Selatan

SJ = Sijunjung

$\mathrm{LK}=50 \mathrm{Kota}$

SS = Solok Selatan

AG =Agam

$\mathrm{PD}=$ Padang

$\mathrm{SL}=$ Solok

TD = Tanah Datar

$\mathrm{DR}=$ Dharmasraya

Gambar 4 Densitas Total Curah Hujan Bulanan Sumatera Barat. a) Desember, Januari, Februari (DJF). b) Maret, April, Mei (MAM). c) Juni, Juli, Agustus (JJA). d) September, Oktober, November (SON) 
Gambar 4 menunjukkan distribusi curah hujan selama 16 tahun pengamatan TRMM 3B43 (1998-2013). Secara umum dapat diamati bahwa curah hujan di Sumatera Barat lebih tinggi pada periode DJF dan MAM. Hal ini konsisten dengan penelitian Aldrian dan Susanto (2003) dan Marzuki dkk. (2016b) yang menemukan bahwa curah hujan sebagian Sumatera termasuk Sumatera Barat mempunyai dua puncak yaitu Desember-Januari dan April-Mei. Namum, hal ini agak berbeda dengan pola petir dimana petir selama SON lebih banyak daripada periode MAM (Gambar 2). Hal ini kemungkinan mengindisikan bahwa hujan pada peride SON tidak diikuti oleh petir yang banyak.Total curah hujan untuk semua bulan lebih tinggi di sekitar pantai dibandingkan dengan daratan. Hal ini konsisten dengan Ogino dan Yamanaka (2016) yang menemukan bahwa 34\% total curah hujan di kawasan tropis terjadi di kawasan pesisir pantai dalam jarak $300 \mathrm{~km}$ dari garis pantai.

Hubungan antara curah hujan dan petir sulit teramati dari Gambar 2 dan Gambar 4. Jika dilihat dari pola petir (Gambar 2) dan total curah hujan (Gambar 4) terlihat bahwa distribusi petir lebih banyak di daratan sementara densitas kilatan curah hujan lebih tinggi di lautan. Untuk melihat hubungan korelasi antara curah hujan dan petir secara lebih jelas dilakukan regresi total curah hujan dan petir bulanan dalam grid $0,25^{\circ}$ untuk setiap kabupaten di Sumatera Barat.

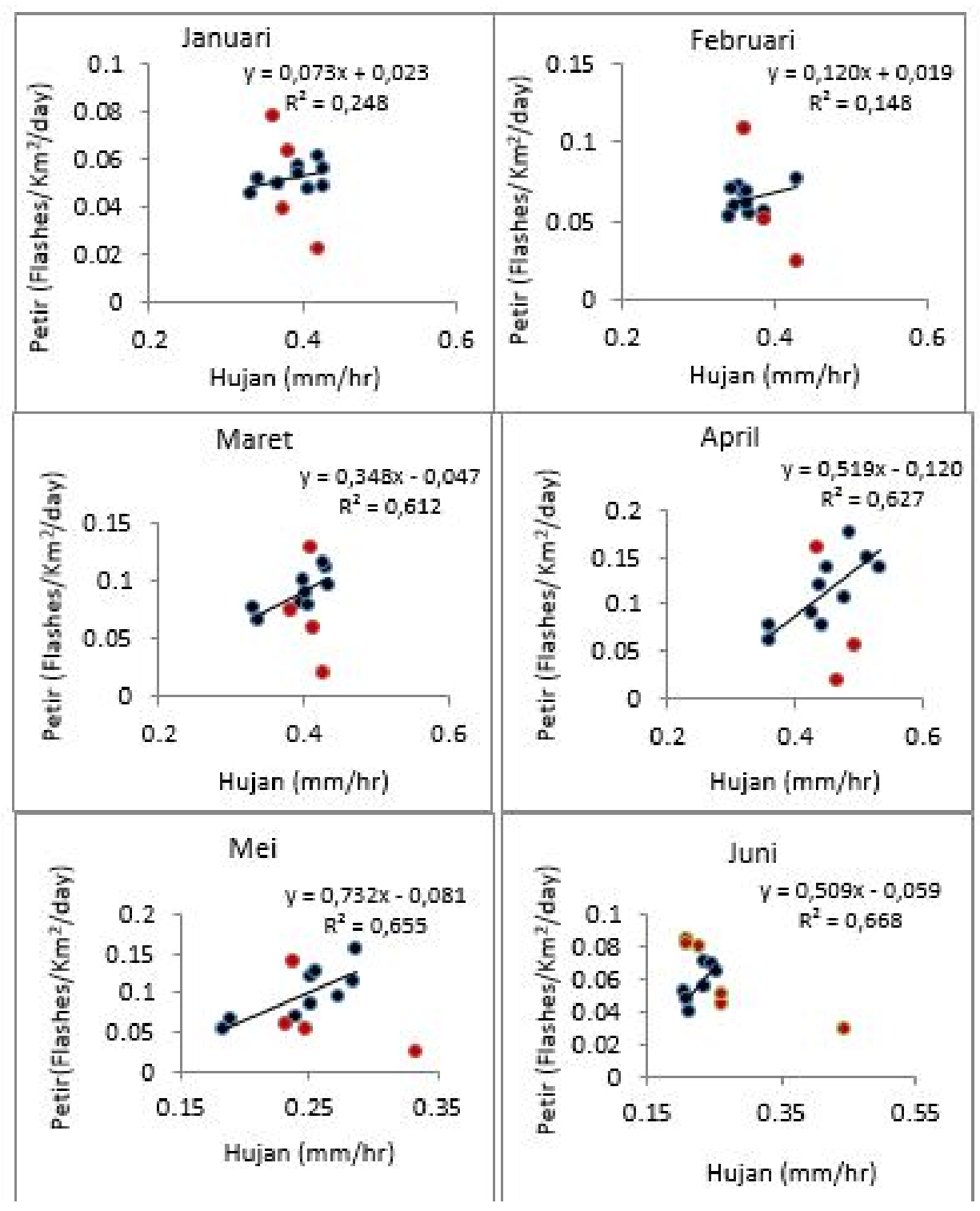

Gambar 5 Grafik Hubungan Antara Petir dan Curah Hujan Bulan Januari-Juni. (Titik hitam adalah kabupaten yang hubungan antara petir dan hujannya kuat sedangkan titik merah dalah kabupaten yang hubungan petir dan hujannya rendah) 
Gambar 5 dan Gambar 6 menunjukkan grafik hubungan antara petir dan hujan untuk daerah Sumatera Barat meliputi Kepulauan Mentawai, Pesisir Selatan, Pasaman Barat, Pasaman, Agam, Solok Selatan, Solok, Dharmasraya, 50 Kota, Sijunjung, Padang Pariaman, Kota Padang, dan Tanah Datar. Titik berwarna hitam adalah kabupaten dimana petir dan curah hujan mempunyai hubungan (korelasi) sedangkan titik bewarna merah adalah kabupaten yang memiliki korelasi sangat rendah. Data dengan hubungan yang lemah tidak diikutkan dalam perhitungan koefisien korelasi.Pada bulan Januari kabupaten yang memiliki korelasi sangat rendah antara petir dan hujannya adalah kepulauan Mentawai, kabupaten Pesisir Selatan, Sijunjung dan Dharmasraya. Sementara kabupaten lain memiliki hubungan dengan nilai $R^{2}$ sebesar 0,248 .

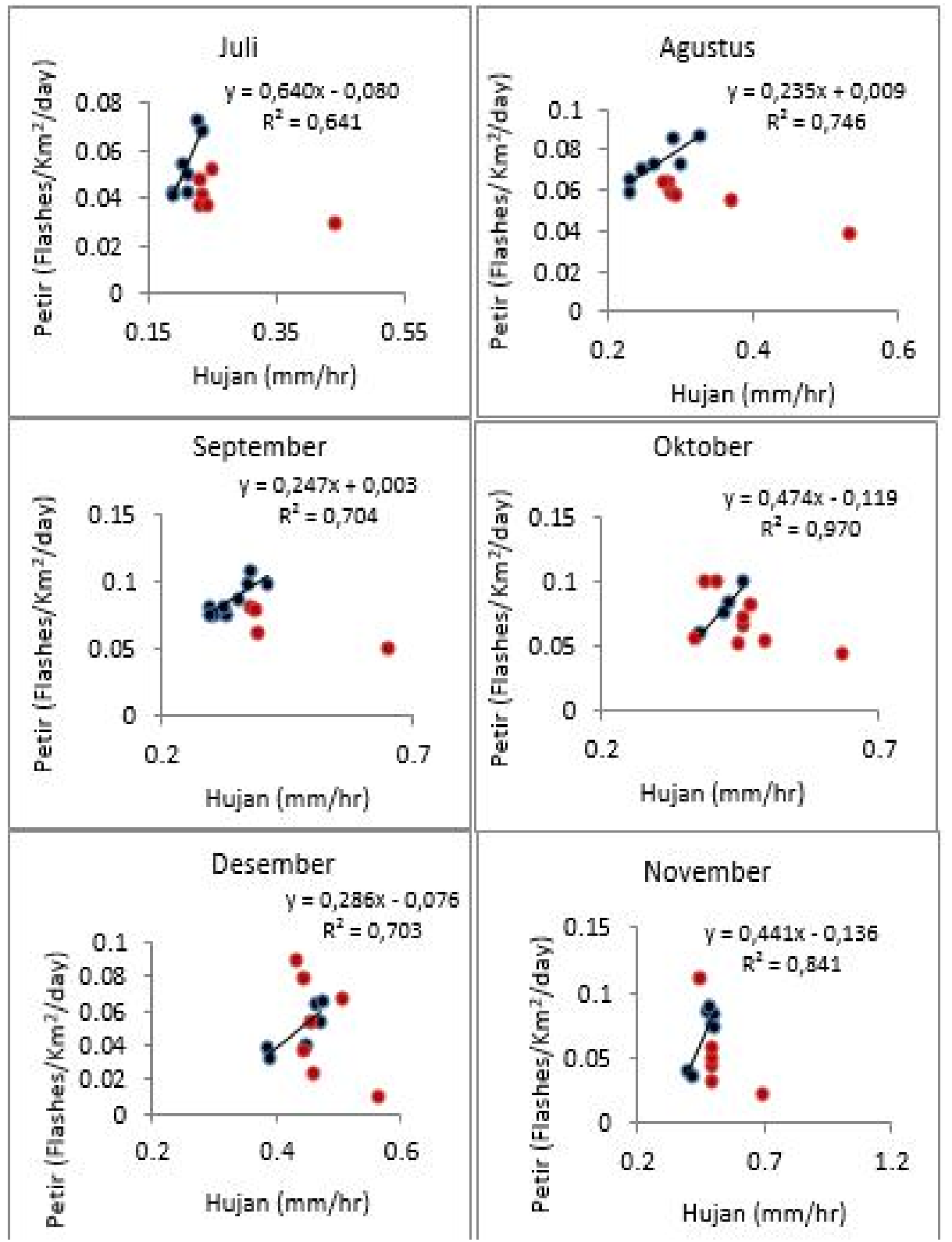

Gambar 6 Grafik Hubungan antara Petir dan Curah Hujan bulan Agustus-Desember

Pada bulan Februari kabupaten yang memiliki korelasi sangat rendah adalah Kepulauan Mentawai, Agam, Dharmasraya dan Tanah Datar. Sementara itu, pada bulan maret terdapat empat kabupaten dengan korelasi yang sangat rendah antara hujan dan petirnya yaitu Kepulauan Mentawai, Pesisir Selatan, Pasaman Barat dan Dharmasraya. Kabupaten yang memiliki korelasi sangat rendah untuk bulan lain (Gambar 6) meliputi daerah yang dekat dengan laut seperti 
Kepulauan Mentawai, Pesisir Selatan, Pasaman Barat, Agam (bulan Juli, September, Oktober, November).

Hubungan yang cukup kuat teramati pada bulan Oktober yaitu di Kabupaten Solok, Solok Selatan, 50 Kota dan Padang Pariaman. Selain itu, pada bulan November hubungan yang kuat terjadi di kabupaten Pasaman, Solok, Solok Selatan, 50 Kota, Sijunjung, Padang Pariaman dan Kota Padang. Dari keseluruhan plot grafik daerah dengan hubungan yang cukup kuat adalah kabupaten Solok, Solok Selatan, Padang Pariaman, dan 50 kota (bulan Oktober) dengan nilai $R^{2}$ $=0,970$ sedangkan daerah dengan hubungan yang tidak kuat meliputi daerah kepulauan Mentawai, Pesisir Selatan dan Dharmasraya. Dengan demikian dapat disimpulkan bahwa untuk daerah dekat laut hubungan antara petir dan hujan sangat rendah sedangkan di darat terdapat hubungan yang kuat antara petir dan hujan untuk beberapa kabupaten.

\section{KESIMPULAN}

Penelitian ini menunjukkan bahwa distribusi spasial dan temporal petir di Sumatera Barat bervariasi antara satu daerah dengan daerah lainnya. Secara umum, petir lebih banyak terjadi di darat dibandingkan laut konsisten dengan karakteristik petir secara umum. Intensitas petir tertingi di daratan Sumatera Barat teramati selama selama periode DJF di Kabupaten Dharmasraya. Intensitas petir di Sumatera Barat menunjukkan variasi diurnal yang signifikan dimana ditemukan bahwa petir paling banyak terjadi pada sore hari yaitu mulai pada jam 16.00 LST hingga tengah malam sedangkan pada jam 00.00 LST hingga 12.00 LST densitas kilatan petir yang terjadi sangat rendah. Pola diurnal petir ini konsisten dengan pola migrasi awan dari laut ke daratan Sumatera yang ditemukan oleh peneliti sebelumnya. Hubungan curah dan petir di Sumatera Barat juga bervariasi antara satu kabupaten dengan kabupaten lainnya. Regresi linier antara petir dan curah hujan menunjukkan bahwa daerah yang memiliki korelasi yang cukup kuat antara densitas petir dan curah hujannya adalah Kabupaten Solok, Solok Selatan, Pasaman, dan 50 Kota sedangkan daerah yang memiliki korelasi yang sangat rendah adalah Kepulauan Mentawai, Pesisir Selatan, dan Agam. Dengan demikian, di beberapa kabupaten petir dapat menjadi indikator untuk penentu curah hujan tetapi tidak untuk beberapa kabupaten yang lain..

\section{UCAPAN TERIMA KASIH}

Penulis mengucapkan terima kasih kepada National Aeronautics and Space Administration (NASA) yang telah menyediakan data TRMM untuk penelitian ini secara gratis.

\section{DAFTAR PUSTAKA}

Albrecht, R.I., Goodman, S.J., Buechler, D.E., Blakeslee, R.J., Christian, H.J., 2015, Where are the lightning hotspots on Earth?, Bulletin of the American Meteorological Society.

Aldrian, E., dan Susanto, R.D., 2003, Identification of three dominant rainfall regions within Indonesia and their relationship to sea surface temperature, International Journal of Climatology, Vol. 23, hal. 1435-1452

Cardoso, I., 2014, Lightning Casualty Demographics in Brazil and Their Implications for Safety Rules, Atmospheric Research, Vol. 135-136, hal. 374-379.

Carey, D.L. dan Rutledge, A.St., 2000, The Relationship Between Precipitation and Lightning in Tropical Island Convektion ; A C-Band Polarimeter Radar Study, Monthly Weather Review, Vol. 128, hal. 2687-2710.

Hutchins, M.L., Holzworth, R.H., Rodger, C.J., dan Brundell, J.B., 2012, Far-Field Power of Lightning Strokes as Measured by the World Wide Lightning Location Network, Journal of Atmosphere Oceanic Technology., Vol. 29, hal. 1102-1110.

Kozak, S.A, 1998, Lightning strikes in Alberta thunderstoms: Climatology and Case Studies, Tesis, Master of Science, University of Alberta, Edmonton.

Lay, E.H., Jacobson, A.R., Dowden, R.L., Holzworth, R.H., Rodger, C.J., 2007, Local Time Variation In Land/Ocean Lightning Flash Density As Measured By The World Wide Lightning Location Network, Journal Of Geophysical Research, Vol. 112, Hal. 1-9. 
López, R.E., Holle, R.L., dan Heitkamp, T.A., 1995, Lightning Casualties and Property Damage in Colorado from 1950 to 1991 Based on Storm Data, Weather and Forecasting, Vol. 10, hal. 114-126.

Marzuki, Hashiguchi, H., Yamamoto, M.K., Yamamoto, M., Mori, S., Yamanaka, M.D., Carbone, R.E., Tuttle, J.D., 2013, Cloud episode propagation over the Indonesian Maritime Continent from 10 years of infrared brightness temperature observations, Atmospheric Research, Vol. 120-121, hal. 268- 28.

Marzuki, Hashiguchi, H., Kozu, T., Shimomai, T., Shibagaki, Y., dan Takahashi, Y., 2016a, Precipitation microstructure in different Madden-Julian Oscillation phases over Sumatera, Atmospheric Research, Vol. 168, hal. 121-138.

Marzuki, Hashiguchi, H., Shimomai, T., and Randeu, W. L., 2016b, Cumulative Distribution of Rainfall Rate over Sumatra, Progress In Electromagnetics Research M, Vol. 49, pp. 1-8

Mori, S., Hamada, J.I.., Tauhid, Y.I., Yamanaka, M.D., Okamoto, N., Murata, F., Sakurai, N., Hashiguchi, H., dan Sribimawati, T., 2004, Diurnal Land-Sea Rainfall Peak Migration over Sumatera Island, Indonesian Maritime Continent, Observed by TRMM Satellite and Intensive Rawinsonde Soundings, Monthly Weather Review, Vol. 132, hal. 2021-2039.

Pemprov Sumatera Barat, 2014, Status Lingkungan Hidup Daerah Provinsi Sumatera Barat 2014, Bapedalda Provinsi Sumatera Barat.

Seaman, L.W., 2000, Evolution Of Cloud-to-Ground Lightning Discharge in Tornado Thunderstorms, Tesis, Air force Institute of Technology, Ohio.

Septiadi, D. dan Hadi, S., 2011, Karakteristik Petir Terkait Curah Hujan Lebat Di Wilayah Bandung, Jawa Barat, Jurnal Meteorologi Dan Geofisika, Vol. 12, hal. 163-170

Soula, S, 1998, The CG Lightning Activity Of Storm Causing A Flashflood, Geophysical Research Letter, Vol. 25, hal. 1181-1184.

Uman, M.A., 2001, The Lightning Discharge, Mineola, New York, Dover Publications.inc.

Vadreas, A.K., Emeraldi, P., dan Hazmi, A., 2014, Sistem Informasi Petir (SIP) dengan Metode Lightning Distribution (LD), Jurnal National Teknik Elektro, Vol. 3, Hal. 177-182.

Valdivia, J.A., 1997, The Physics of High Altitude Lightning, Disertasi, Department of Physics, University of Maryland, Maryland.

Virts, K.S., Wallace, J.M., Hutchins, M.L., dan Holzworth, R.H., 2013, Highlights of a New Ground-Based, Hourly Global Lightning Climatology, Bulletin American Meteorology Society, Vol. 94, hal.1381-1391.

Zheng, D., Zhang, Y., Meng, Qing, Chen, L., dan Jianru, C 2016, Climatological Comparison of Small and Large-Current Cloud-to-Ground Lightning Flashes over Southern China, Journal of Climate, Vol. 29, hal. 2831-2848. 